\title{
MANFAAT KOMPETENSI GURU TERHADAP PRESTASI BELAJAR
}

\author{
Dr. Mortan Sibarani, M.Pd.K. \\ Sekolah Tinggi Teologi Injili Arastamar (SETIA) Jakarta \\ msibarani@sttsetia.ac.id
}

\section{Abstrak}

Kompetensi yang seharusnya dimiliki seorang guru yakni kompetensi kepribadian, kompetensi pedagogik, kompetensi profesional dan kompetensi sosial maupun kompetensi kerohanian (spritual). Berkaitan dengan faktor guru yang begitu menentukan di dalam kegiatan belajar mengajar, dalam bagian ini dibahas manfaat Kompetensi Guru bagi Kemajuan Prestasi Belajar Murid. Hal ini berarti kemampuan atau kecakapan, berkaitan dengan pemilikan, pengetahuan atau kecakapan maupun ketrampilan sebagai guru.

Kata Kunci: Kompetensi, guru, prestasi

\section{Pendahuluan}

Masalah kompetensi guru masih masalah yang serius bagi sebagian guru di Indonesia. Guru masih banyak menjalankan kinerjanya dengan seadanya tanpa mempunyai kompetensi guru yang memadai, sebagaimana yang diharapkan masyarakat kita. Sebagai contoh, penelitian terhadap 121 guru bahasa Indonesia di Palembang, Yogyakarta-Sleman, Surabaya, Ambon dimana hanya 56, 2 persen dari guru tersebut menjadi pembaca mandiri dan memahami bacaannya, dan hanya 57,8 persen guru yang diteliti itu secara sadar menulis dengan ejaan yang benar (Kompas 7 Desember 2018).

\section{PENGERTIAN KOMPETENSI GURU}

Dalam system kemajuan ilmu dan tehnologi, sangatlah sulit mengorganisasi pembelajaran apabila guru tidak mempunyai kompetensi yang tinggi. Salah satu ketertinggalan pendidikan di negara Indonesia sekarang ini adalah minimnya kompetensi guru dalam menjalankan tugasnya sebagai pendidik dan pengajar. Guru kurang profesional dalam menjalankan tugasnya.

Menurut kamus besar bahas Indonesia, kompetensi adalah (kewenangan) kekuasaan untuk membentuk atau memutuskan suatu hal. Dalam arti spesifik adalah kemampuan melaksanakan sesuatu yang diperoleh melalui pendidikan dan pekerjaan yang berulang-ulang dilaksanakan sehingga mempunyai kematangan, kelancaran dan keahlian. Pendapat ini timbul karena setiap orang mempunyai kemampuan masingmasing dalam malaksanakan sesuatau pekarjaan.

Sopianti menyatakan bahwa kompetensi guru merupakan kemampuan yang digunakan sebagai standar kinerja seorang yang diharapkan dapat berkontribusi positif terhadap kinerja organisasi. Guru sebagai yang berada dalam organisasi kependidikanmempunyai tanggung jawab yang besar. Jadi guru sebagai pendidik dan masa depan anak atau peserta didik, jelas memerlukan kompetensi yang memadai agar proses belajar mengajar yang dapat memberi pengaruh yang signitif bagi prestasi peserta didik dalam situasi yang semakin kompetitif. Seorang guru aktif 
apabila dalam memberikan layanan proses belajar mengajar dapat menggabungkan kompotensi yang dimiliki dalam kinerjanya dalam mencapai tujuan pengajaran.

Menurut Abdul, kompetensi adalah suatu ukuran yang telah ditetapkan dan merupakan persyaratan dalam bentuk penguasaan pengetahuan dan perilaku, sehingga layak seorang guru dalam menduduki jabatan fungsional, sesuai dengan tugas kualifikasi proses pembelajaran. Kompotensi merupakan suatu ukuran kemamapuan yang memiliki seseorang guru dan merupakan persyaratan untuk menduduki suatu jabatan fungsionalnya sehingga layak disebut guru yang profesional.

Siapakah Guru Itu ?Dalam kamus besar bahasa Indonesia, istilah guru adalah orang yang pekerjaannya (mata pencariannya, profesinya) mangajar. Definisi yang dikenal sehari-hari adalah bahwa guru merupakan orang yang harus digugu dan ditiru, dalam arti bahwa orang yang memiliki kemampuan dalam mengajar. Guru adalah orang dewasa yang bertanggung jawab dalam mendidik, mengajar dan membimbing peserta didik. Guru adalah orang yang memiliki kemampuan merancang program pembelajaran serta mampu mengelolah kelas agar peserta didik dapat belajar dan pada akhirnya dapat mencapai prestasi sebagai tujuan akhir pendidikan. Guru merupakan suatu profesi, yang berarti suatu jabatan yabg memerlukan kompetensi yaitu keahlian khusus sebagai guru dan tidak dapat dilakukan oleh sembarang orang di luar bidang pendidikan

Berdasarkan rumus tentang pengertian kompetensi dan pengertian tentang guru, maka dapat dikemukakan bahwa pengertian kompetensi guru adalah kewenangan atau kekuasaan, dan kemampuan menguasai seperangkat pengetahuan, sikap dan ketrampilan (life skill) dalam bidang ilmu pendidikan keguruan, oleh pengajar dan pendidik, yang dihayati, dikuasai, dan diterapkan dalam mengajar, mendidik dan mengatasi masalah yang dihadapi secara cerdas dan bertanggung jawab.

\section{JENIS-JENIS KOMPETENSI GURU}

Kompotensi adalah kemampuan melaksanakan sesuatu yang diperoleh melalui pendidikan dan latihan, sehingga istilah kompetensi sangat konstektual dan tidak universal untuk semua jenis pekerjaan setiap jenis pekerjaan memerlukan porsi yang berbeda-beda antara pengetahuan, sikap, dan ketrampilannya. Kompetensi guru dalam undang-undang No. 14 tahun 2005 pasal 8 tentang guru dan dosen mengatakan, guru wajib memiliki kualifikasi akademik, kompetensi, sertifikat pendidikan, sehat jasmani dan rohani, serta memiliki kemampuan untuk mewujudkan tujuan pendidikan nasional, selanjutnya pasal 10 (1) mengatakan kompetensi guru sebagaimana yang dimaksud dalam pasal 8 meliputi kopetensi pedagogik, kompetensi kepribadian, kompetensi profesional, kompetensi sosial, kompetensi moral, kompetensi spiritual yang dapat diperoleh dari profesi dari kompetensi guru di atas dapat dijabarkan jenis-jenis kompetensi sebagai berikut:

\section{a. Kompetensi Paedagogik}

Pembelajaran adalah menuntut siswa untuk memahami apa yang sedang dipelajari. Kegiatan penbelajaran dilakukan dalam lembaga-lembaga pendidikan atau pun berdasarkan berbagai pengalaman dimasyarakat. "padagogik berasal dari bahasa 
Yunani yakni 'pedos' yang artinya laki-laki, dan 'agogos' yang artinya mengatur, membimbing. Jadi pedagogik secara harafiah membantu anak laki-laki pada zaman yunani kuno yang pekerjaannya mengantar anak majikannya ke sekolah.

Menurut Prof. Dr. J. Hoogeveld(Belanda) pedagogik adalah ilmu yang mempelajari masalah membimbing anak kearah tujuan tertentu, supaya kelak ia mampu secara mandiri dan menyelesaikan tugas hidupnya. Kompetensi di dalam penjelasan peraturan pemeritah nomor 19 tahun 2005 tentang standar nasional pendidikan, pasal 28, menyebut kompetensi ialah:

1. Kemampuan mengelola pembelajaran.

Guru diharapkan membimbing anak untuk mengemgangkan kurikulum dn pelajaran secara efektif serta melakukan pengawasan dalam pelaksanaan. Guru merupakan seorang manejer dalam pelajaran yang bertanggung jawab, terhadap perencanaan, pelaksanaa, dan penilaian perubahan atau perbaikan program pembelajaran.

2. Pemahaman tentang peserta didik

Pemahaman terhadap prestasi peserta didik merupakan suatu perancangan dan pelaksanaan pembelajaran, evaluasi hasil belajar mengembangkan peserta didik untuk mengaktualisasi berbagai potensi yang dimilikinya.

3. Perencanaan pembelajaran,

Perencanaan pembelajaran merupakan salah satu salah satu kompotensi pedagogik yang harus dimiliki oleh seorang guru yaitu :Menguasai landasan mengajar, menguasai ilmu mengajar, mengenal siswa, menguasai teori motivasi. menguasai lingkungan masyarakat, menguasai penyusunan kurikulum. menguasai teknik penyusunan RPP, menguasai pengetahuan evaluasi pelajaran. Selain itu guru juga harus memahami tingkat kemampuan peserta didik. Guru harus cakap merencanakan pembelajaran. Guru membuat Syalabus setiap semester. Jadi kompetensi paedagogik berarti kemampuan nguru tentang cara mengajar atau tehnik menyampaikan materi pelajaran.

\section{b. Kompetensi Profesional}

Undang-undang nomor 14 tahun 2005 tentang guru dan dosen, mendefinisikan guru sebagai "pendidikan profesional dengan tugas utama mendidik, mengajar, membina, mengarahkan, melatih, menilai dan meng evaluasi peserta didik pada pendidikan anank usia dini formal, pendidikan dasar, dan pendidikan menengah. Kata "profesional" berasal dari kata "profesi" yang artinya bidang pekerjaan yang dilandasi dengan keahlian, ketrampailan dan kemampuan khusus. Buchari Alma menyatakan,"profesi sebagai suatu pekerjaan yang mempunyai fungsi pengabdian pada masyarakat dan ada pengakuan dari masyarakat. Profesi berarti kondisi, keadaan, suatu pencernaan. Profesi adalah suatu jabatan yang menuntun keahlian dari pada anggotanya. Profesi adalah suatu yang menuntun keahlian dan kemampuan khusus yang dimiliki guru dalam hal ketampilan mengajar yang dapat diakui di lingkungan masyarakat. Guru juga harus mempunyai kemampuan dalam mengembangkan pengetahuannya, sehingga dapat menganalisa pelajaran yang disampaikan. Untuk menwujudkan semua ini guru dituntut memiliki intelektual yang cukup. Seorang guru harus memiliki pikiran yang jauh melampaui peserta didik, kalau tidak bisa berhak menjadi guru. 
Sidjabat menyatakan seorang guru profesional benar-benar ahli dibidangnya,menguasai keilmuan atau apa yang digelutinya (termasuk bidand teologi). Untuk tujuan itu, guru harus berusaha mengembangkan empat perkara:

1. Memahami materi ajar yang ada dalam kurikulum sekolah.

2. Memahami struktur, konsep, dan metode ilmu yang menanungi atau koheren dengan materi ajar

3. Memahami hubungan antar konsep antar mata pelajaran yang berkait.

4. Menerapkan konsep-konsep keilmuan dalam hidup sehari-hari.

Standar pendidikan nasional menjelaskan, pasal 28 ayat 3 butir mengartiakan bahwa "kompetensi profesional adalah kemampuan menguasai materi pembelajaran secera luas dan mendalam yang memungkinkan membimbing pesrta didik memenuhi standar yang ditetapkan dalam standar pendidikan nasional. Jadi dari pendapat diatas dapat disimpulkan bahw seorang profesional adalah guru yang dapat menguasai materi secara mendalam dan luas, untuk dapat mempelajari peserta didik dengan baik sesuai yang dilakukan seorang guru.Kompetensi pertama dimiliki seorang guru profesional adalah penguasaan materi pelajaranPenguasaan ini menjadi landasan pokok untuk ketpampilan mengajar, yang mampu mengetahui, memahami mengaplikasikan dan menganalisis sejumlah pengetahuan yang dimiliki. Seperti yang dikemukakan oleh Yusak Panggabeam" Guru mengetahui bahan ajar. Bahan ajar adalah media pencapaian tujuan pengajaran, pendalaman bahan ajar memiliki kemungkinan dalam pembentukan siswa.

\section{c. Kompetensi sosial}

Kompetensi yang dimaksud adalah kompetensi sosial di dalam peraturan pemerintah nomor 19 tahun 2005 pada pasal 28, ayar 3, ialah kemampuan pendidik sebagai bagian dari masyarakat untuk berkomonikasi dan bergaul secara efektif dengan peserta didik, sesama pendidikan, tenaga pendidikan, orang tua wali peserta didik dan masyaraka sekitar. Menurut Ahmat Sanusi (1991) mengungkapkan kompetensi sosial mencakup kemampuan untuk menyesuiakan diri kepada tuntutan kerja dan lingkungan sekitar pada waktu membawa tugasnya sebagai guru. Kompetensi sosial dalam kegiatan belajar ini berkait erat dengan kemampuan guru dalam berkomonikasi dengan masyarakat disekitar sekolah dan kasyarakat guru tinngal sehingga peranan dan cara guru berkokonikasi dengan masyarakat diharapkan memiliki karakteristik tersendiri yang sedikit banyak berbeda dengan orang lain yang bukan guru. Misi yang diemban guru adalah kemanusian. Mengajar dan mendidik adalah misi tugas memanusiakan manusia. Guru harus memiliki kompotensi sosial karena guru adalah penceramah jaman (Langeved, 1955). Menurut Cece Wijaya (1994) dalam Djama'an Satori (2007;2.17) kompotensi sosial sebagai berikut.

1. Terampil berkomonikasi dengan peserta didk atau orang tua peserta didik.

2. Bersikap simpatik.

3. Dapat bekerja sama dengan dewan pendidikan/komite sekolah.

4. Pandai bergaul dengan kawan sekerja dan mitra pendidikan.

5. Memahami dunia sekitar(Lingkungan)

Sedangkan menurut Mulkhas Samani (2008;6) yang dimaksud dengan kompetensi sosial ialah kemampuan individu sebagai bagian masyarakat mencakup kemampuan untuk; 
1. Berkomonikasi lisan, tulisan, atau isyarat.

2. Menggunakan teknologi dan komonikasidan informasi secara fongsional.

3. Bergaul secara efektif dengan peserta didik sesama pendidik, tenaga kependidikan pimpinan satuan pendidikan, orang tua/ wali peserta didik.

4. Bergaul secara santun dengan masyarakakt sekitar dengan mengindahkan norma serta sistem nilai yang berlaku.

5. Menerapkan pribsip-prinsip persaudaraan sejati semangat dan kebersamaan.

Berdasarkan kompotensi sosial seperti tersebut di atas, maka inti dari kompetensi sosial itu adalah kemampuan guru melakukan interaksi sosial melalui komonikasi. Guru dituntut bekomonikasi dengan kepala sekolah, sesama guru, siswa, orang tua siswa, dan masyarakat sekitar, dan lain-lain. Jadi guru dituntut mengenal banyak kelompok seperti kolompok bermain, kelompok kerja sama. Guru harus cakap berkomunikasi. Kecakapan berkomunikasi meliputi kepribadian ramah, sopan, bertutur kata yang baik, jujur, suka menolong dan menjadi teladan di tengah-tengah masyarakat..

\section{d. Kompetensi Kepribadian}

Kepribadian guru adalah keseluruhan dari individu yang terdiri dari unsur psikis dan fisik. Dalam Makna demikian, seluruh sikap seseorang merupakan suatu gambaran dari kepribadian orang itu, asal dilakukan secara sadar. Dan perbuatan baik sering dikatakan bahwa seorang guru itu mempunyai kepribadian baik atau beraklak mulia. Sebaliknya, bila seseorang melakukan sikap dan perbuatan yang tidak baik menurut pandangan masyarakat, maka dikatakan orang mempunyai kepribadian baik atau tidak beraklak mulia, Oleh karna itu masalah kepribadian adalah suatu yang menentukan tinggi rendahnya kewibawaan seseorang adalah pandangan siswa atau masyarakat.

Kemudian Mulyasa menyatakan bahwa, kepribadian yang sesungguhnya adalah abstrak, suak dilihat dan diketahui secara nyata, yang dapat ditampilkan atau bekasnya dalam segala segi dan aspek kehidupan, kepribadian adalah keseluruhan individu yang terdiri dari sifat atau perbuatan, yang sering-sering dikatakan orang bahwa itu mempuyai pribadi yang diteladani.

Berdasarkan beberapa pendapat di atas dapat disimpulkan bahwa, kepribadian seseorang dapat dilihat dari dua segi yaitu sifat yang pura-pura dan dapat disebenarkan yang merupakan sesuatu yang nyata. Begitu juga demikian pribadi guru dapat dipahami sebagai "tuntutan kepbribadiannya, guru sebagai pendidik. Guru dapat diguguhkan dan diteladani, diguguh maksudnya pesan-pesan yang di sampaikan guru bisa dipercaya dan dilaksanakan dan pola hidup bisa ditiru atau diteladani.

Syaiful Sagala menyatakan bahwa, sekali saja guru didapati berbohong langsung kepada muridnya niscaya hal itu menghancurkan nama baik dan kewibawaan seorang guru, yang pada gilirannya akan berakibat fatal dan melanjutkan tugas proses belajar mengajar. Dengan demikian masalah kepribadian guru merupakan hal yang menentukan keberhasilan dalam melaksanakan tugasnya sebagai pendidik.

Kepribadian adalah unsur yang menentukan keakraban hubungan guru dengan peserta didik dalam hal yang baik. Guru yang baik dapat bertanggung jawab akan dapat mempengaruhi peserta didik untuk menjadi orang yang baik dalam kehidupan sehari-hari, dan bertagung jawab. Jadi kompetensi pribadi adalah kemampuan 
pribadi atau personal yang meliputi perilaku hidup yang diteladani baik oleh peserta didik maupau masyarakat.

Kompetensi pribadi guru terkait dengan penampilan sosok guru sebagai individu yang mempuyai kedisiplinan, berpenampilan baik, tanggung jawab, memiliki komitmen menjadi teladan yang dapat ditiru peserta didik, guru adalah penuntun. Jadi sebagai seorang guru yang diteladani peserta didik harus lebih dahulu bertekad mendidik dirinya sebelum sebelum mendidik orang lain Homrighausen mengemukakan bahwa guru harus rohani bisa memberiakn teladan dan mempunyai hati yang lemah lembut sebagai seorang pelayan.

Wina Sanjaya menngatakan, Guru adalah sebagai seorang model, guru harus memiliki kompotensi yang berhubungan dengan perkembangan kepribadian yang di antaranya: pertama, kemampuan yang berhubungan dengan pengajaran ajaran agama sesuai dengan keyakinan agama yang dianut, kedua, mampu untuk menghormati dan menghargai antara umat beragama, ketiga, kemampuan berperilaku sesuai dengan norma, aturan dan sistem nlai yang berlaku dengan masyarakat, keempat, mengembangkan sikap-sikap terpuji sebagai seorang guru misalnya sopan santun dan tata krama serta bersikap demokrasi dan terbuka terhadap pembaruan dan praktik.

Ada bebera hal yang perlu dimiliki oleh seorang guru dalam pribadinya yaitu:

1. Memiliki kepribadian yang mantap, stabil, dan dewasa.

Guru harus memiliki pribadi yang dewasa karena banyak masalah pendidikan yang disebabkan oleh faktor kepribadian kurang dewasa kondisi kepribadian yang demikian sering membuat guru melakukan tindakan-tindakan yang tidak profesional,tidak terpuji, bahkan tindakan-tindakan tidak senonoh merusak citra dan martabat guru

2. Disiplin arif dan berwibawa.

Banyaknya peserta didik yang berlaku kurang senonoh dimasyarakat terlibat vcd porno, narkoba dan pelanggaran lainnya. Berangkat dari pribadi yang kurang disiplin. Oleh karena itu peserta didik harus didisiplin, dan gurulah yang memulainya.sebagai guru penting memiliki disiplin, arif dan berwibawa

3. Menjadi teladan bagi peserta didik.

Pada dasarnya perubahan perilaku yang dapat ditunjukan oleh peserta didik di pengaruhi oleh latarbelakaabg pendidikan dan pengalaman yang dimiliki oleh seorang guru atau dengan kata lain. Guru mempunyai pengaruh terhadap prestasi belajar peserta didik untuk itilah guru menjadi contoh teladan bagi peserta didik.

4. Beraklak mulia

Guru harus beraklak mulia, karena ia adalah seorang penasehat bagi peserta didik, bahkan bagi orang tua meskipun mereka tidak memiliki dalam penasehat. Maka efektif guru menangani setiap permasalahan.

Kompetensi kepribadian sangat besar pengaruh terhadap pertumbuhan dan perkembangan pribadi peserta didik. Kompetensi kepribadian ini memiliki peran dan fungsi yang sangat peting dalam pembentukan kepribadian anak, dulu mengembangkan proses pembelajaran dengan baik.

Sehubungan dengan uraian di atas, maka dapat disimpulkan bahwa setiap guru dituntut memiliki kompotensi kepribadian yang memadai, bahkan kompetensi ini akan menjadi landasan bagi kompetensi-kompetensi lainnya. Guru hanya tidak dituntun untuk mampu memakai metode pembelajaran, tetapi yang paling penting 
adalah bagaimana guru menjadikan proses pembelajaran sebagai jejang pembentukan kompetensi dari perbaikan kualitas pribadi peserta didik.

\section{e. Kompetensi Spiritual}

Kompetensi spiritual adalah kemampuan pendidikan yang berkaitan dengan hal-hal yang berasalatau yang sumber dari Tuhan, yang menjadi bagian hidup dari seorang guru PAK sebagai bagian dari masyarakat untuk berkomunikasi dan bergaul secara efektif dengan peserta didik, sesama pendidik, tenaga kependidikan, orang tua peserta didik dan masyarakat sekitar dengan roh atau jiwa, pikiran dan hati nurani. Untuk sikap seorang guru mengajar harus mencerminkan sesuaru yang baik dalam pola hidupnya seperti yang ada tertulis dalam 1 timotius 4:16 awasilah dirimu sendiri da wasilah ajaranmu. Bertekunlah dalam semuanya itu, karena dalam berbuat demikian engkau akan menyelamatkan dirimu dan semua orang yang mendengar engkau. Oleh karena itu seorang guru dalam mendidik dan mengajar perlu bersandar penuh kepada Tuhan dan mendekatkan diri pada-Nya agar dapat membimbing dan mengubah perilaku peserta didik.

Guru adalah pribadi yang memiliki spiritaul yang karenanya perlu melakukan pendekatan dan menyentuh aspek nilai kepercayaan dan spritual. oleh karena itu seorang guru harus memiliki kompotensi spiritual yang dapat mengembangkan kemampuan profesional keguruannya dalam proses pengajarannya yang dapat diteladani oleh orang lain terutama peserta didik. Karena kita adalah guru pendidikan agaam kristen, maka kompetensi spirutual adalah merupakan persyaratan khusus yang harus dimiliki. Kompetensi spiritual meliputi:

1. Memilki kerohanian yang baik.

2. Mampu menyaktualisasi imannya.

3. Memiliki semangat rohani.

4. Memiliki daya tahan rohani yang kuat.

5. Menjunjung tinggi nilai-nilai kerohanian dalam praktek hidup sehari-hari.

Jadi guru haru mempunyai rohani yang baik agar dapat menjadi teladan bagi peserta didiknya, khususnya guru-guru Kristen harus membawa terang Kristus bagi lingkungannya, Orang Kristen hendaknya semakin sempurna.

\section{PENGERTIAN PRESTASI BELAJAR}

Prestasi belajar adalah hasil yang dicapai seseorang dari proses kegiatan belajar. Prestasi dalam belajar merupakan penguasaan terhadap pengetahaun atau ketrampilan yang dikembangkan oleh mata pelajaran yang dapat dari proses kegiatan belajar yang diukur dalam dari nilai dari hasil nilai yang diberikan oleh guru. Menurut Tulus Tu. U, mengatakan: "prestsi belajar peserta didik adalah hasil belajar yang dicapai peserta didik ketika mengikuti dan mengejarkan tugas dan kegiatan belajar di sekolah."

Menurut Bruner yang di kutip S. Nasutiona ada tiga cara tentang belajar.

1. Informasi, dalam belajar kita mendapatkan informasi baru dan menambahkan pengetahuan yang sudah dimiliki, memperluas dan memperdalam wawasan yang sudah di miliki.

2. Transformasi, informasi itu harus di analisis, dalam bentuk abstrak, agar dapat digunakan dalam bentuk luas. 
3. Evaluasi menilai dan menanamkan kemampuan yang didapatkan dapat bermamfaat dan dapat dipahami.

Penyataan di atas dapat memberikan pengertian tentang belajar yaitu bagaimana peserta didik mendapat gagasan baru untuk mengembangkan pengetahuan yang diperoleh dari ilmu pengetahuan yang sudah dimiliki dan diperdalam memperluas pengetahuan yang sudah dimilik. Belajar juga dapat membentuk pola pikir untuk mengetahui sesuatu yang nyata bahkan membawa peserta didik.

Profesi sebagai guru bukanlah sebagai lapangan pekerjaan, tetapi lebih itu adalah melaksanakan panggilan tugas dan direspon dengan hati nurani yang tulus bekerja. Guru adalah digugu dan ditiru yang cukup mulia.

Guru merupakan salah satu faktor tinggi rendahnya mutu pendidikan. Guru merupakan faktor penting dalam menyukseskan belajar mengajar. Lebih dari itu guru bukan saja terpanggil untuk membagikan ilmu dan pengetahuan, tetapi mampu mengembangkan potensi peserta didik. Untuk mewujudkan semua itu diperlukan kemampuan dan kompotensi seorang guru.

Sedangkan Sardiman memberikan penjelasan tentang arti belajar adalah berubah dalam arti ini yang dimaksud belajar berarti usah mengubah tingkalaku. Jadi belajar membawa suatu perubahan perilaku peserta didik yang sedang belajar. Perubahan tidak hanya berkaitan dengan pengalaman ilmu pengetahuan tetapi juga bentuk kecakapan ketrampilan, sikap pengertian, harga diri, minat, watak dan penyesuain diri.

Jadi belajar dapat membawa perubahan tingkalaku diri peserta didik yang sedang belajar dan perubahan ini, bukan saja dengan penambahan ilmu pengetahuan yang memiliki tetapi dapat membentuk kecakapan, kemauan, ketrampilan, sikap harga diri bahakn menyesuaikan diri peserta didik dengan lingkungan dimana berada.

Kemudian Muhibbin Syah mengartikan "belajar adalah key trem (istilah kunci) yang paling fital dalam setiap usah pendidikan hingga tanpa belajar sesungguhnya tak pernah ada pendidikan. Dari pendapat ini dapat memberikan arti tentang belajar, belajar merupakan kunci pendidikan, tanpa belajar pendidikan tidak pernah ada. Skinner berpendapat bahwa belajar adalah suatu perilaku. Pada saat orang belajr mak responnya akan menjadi lebih baik. Sebaliknya seorang yang tidak belajar maka responnya menurun. Peserta didik yang belajar akan mendapatkan suatu perubahan dalam dirinya untuk menjadi lebih baik. Tetapi peserta didik yang tidak mau belajar maka mengalami kemunduran dalam dirinya, menjadi anak yang tidak baik.

Sedangkan Hilgard dan Bower mengartikan belajar adalah hubungan dengan tingkalaku seseorang terhadap suatu situasi tertentu yang disebabkan oleh pengalaman yang berulang-ulang, dalam situasi itu dimana perubahan tingka laku tidak dapat dijelaskan atas dasar kecenderungan respon pembawaan kematangan keadaan sesaat seorang. Belajar merupakan perubahan tingkalaku yang dialami peserta didik yang didapatkan secara berulang-ulang dari pengalaman dan merupakan dari sifat bawaan. Jadi dari pendapat diatas Dalyono menyimpulkan tentang arti belajar:

1. Belajar adalah suatu usaha, perbuatan yang sungguh-sungguh dengan sistematis mendaya gunakan semua potensi yang dimiliki, baik fisik mental, panca indra, otak dan anggota tubuh lainnya,demikian juga aspek-aspek kejiwaan seperti intelegensi, bakat,motivasi, minat, dan sebagainya. 
2. Belajar mengadakan perubahan didalam diri antara tingkalaku.

3. Belajar merubah kebisaam dari yang buruk menjadai yang baik.

4. Belajar merubah sikap negatif menjadi positif, yang tidak hormar menjadi hormat

5. Belajar menambah pengetahuan dalam berbagai bidang ilmu, misalnya tidak bisa membaca, menulis dan berhitungmenjadi bisa.

Istilah hasil belajar berasal dari bahasa Belajar "prestatie" dalam bahasa indonesia, pretasi belajar adalah hasil usaha. Mahibbin Syah menjelasakan bahwa prestasi belajar nerupakan taraf keberhasilan murid dalam mempelajari materi pelajaran di sekola, dinyatakan dalam bentuk skor yang diperoleh dari hasil tes mengenai jumlah materi pelajaran tertentu. Belajar merupakan suatu proses, suat kegiatan bukan suatu hasil atau tujuan. Belajar bukan hanya mengigat,akan tetepi lebih luas dari itu, yakni mengalami. Hasil belajar bukan suatu penguasaan hasil latihan melainkan pengubahan kelakuan. Selain itu pengaetian lain bahwa. Belajar adalah suatu proses perubahan tingkalaku indifidu melalui interaksi dengan lingkungannya.

Belajar adalah suatu proses dalam melakukan suatu perubahan pada diri seseorang serta prosese dalam mendapatkan pengetahuan, baik pengetahuan kognitif, afektif, dan psikomotorik. Serta mengetahui pengertian belajar menurut kamus besar bahasa Indonesia hasil yang telah dicapai, dalam bidang akademik hasil peserta didik yang diperoleh dari kegiatan persekolahan yang bersifat kognitif dan biasanya ditentukan melalui pengukuran dan penilaian. Dalam belajar peguasaan pengetahuan ketrampilan ketrampilan yang dikembangkan oleh mata peserta didikan lazimnya ditunjukan dengan nilai tes atau angka nilai yang diberikan oleh guru.

Oleh karena itu Prestasi belajar adalah hasil yang telah dicapai setelah melakukan proses belajar mengajar, dan biasanya ditentukan dengan penilaian hasil tes serta ditulis dalam buku rapor.

Nana Sujana menyatakan:

Dicapai oleh peserta dalam buku Tohirin adalah, setelah melakukan kegiaran belajar sering disebut prestasi belajar, tentang apa yang dicapai oleh pesets didik setelah melakukan kegiatan belajar, ada juga yang mengebut dengsn istilah hasil belajar mengajar.pencapaian prestasi belajar adalah hasil peserta didik, merujuk pada aspek-aspek kognitif, afektif dan psikomotorik.

Dengan demikian, hasil belajar peserta didik tersebut tercakup pada tiga ranah yaitu, ranah kognitif, efektif dan psikomotorik dibawah ini akan dijelaskan lebih lanjut.

1. Prestasi belajar ranah kognitif

Ranah kognitif berkenaan dengan hasil belajar intelektual yang terdiri dari enam aspek yaitu:

a. Pengetahuan yang merupakan tipe hasil belajar yang paling rendah. Yang termasuk dalam aspek pengetahuan hafalan seperti rumus, batas, defenisi, istilah, pasal dalam undang-undang, nama-nama tokoh,nama kota dan sebagainya.

b. Pemahaman,yang merupakan hasil belajar lebih tinggi dari pengetahuan. Bentuk pemahaman misalnya menjelaskan sesuatu yang dibaca dan didengar dengan bahasa atau susunan kalimat sendiri. 
c. Aplikasi, yaitu kemampaun untuk menggunakan apa yang telah dipelajari dalam suatu konteks yang baru. Ini mencakup penggunaan peraturan,metode, konsep-konsep hukum dan teori.

d. Analisis, yaitu kemampuan untuk menguraikan suatu materi atau menahan kedalam bagian-bagian sehingga strukturnya dapat dipahami, ini mencakup identikasi bagian, analisis hubungan antar bagian dan pengenalan prinsip-prinsip organisasi yang digunakan.

e. Sintesis, yaitu kemampuan atau bagian-bagian untuk membentuk keseluruhan yang baru. Bagian-bagian tersebut dihubungkan satu sama lain sehingga diperoleh pola atau strutur yang baru.

f. Evaluasi, yaitu pemberian keputusan tentang nilai sesuatu yang memungkinkan dilihat dari segi tujuan gagasan, cara bekerja pemecahan,metode, materi, dan lain- lainnya. Dalam evaluasi diperlukan suatu kriteria terteu untuk memudahkan engetahui tingkat kemampuan evaluasi seseorang.

2. Prestasi belajaar di bidang efektif

Ranah efektif berkenaan dengan sikap dan nilai. Tipe belajar efektif tampak pada siswa dalam berbagai tingkalaku seperti perhatian terhadap pelajaran disiplin, kebiasaan belajar dalam hubungan sosial.

Dalam ranah efektif terdapat lima kategori hasil balajar yaitu:

a. Reciving atau atteding yaitu semacam kepekaan dalam menerima rangsanagan dari luar yang datang kepada siswa dalam bemtuk masalah situasi, gejala dan lain-lainnya.

b. Responsding atau jawaban yaitu reaksi yang diberikan oleh seseorang terhadap stimulasi yang datang dari luar. Hal ini memcakup ketetapan raeksi, perasaan, kepuasan dalam menjawab stimulasi dari luar.

c. Valuing atau penilaian, yaitu kemampuan untuk mendapat memberi penilaian, atau pertimbangan atau pentingnya katerikatan pada suatu objek atau kejadian tertentu dengan reaksi menerima, menolak atau acutakacu.

d. Perorganisasian yaitu perkembangan dari nilai kepada sistem organisasi, termasuk hubungan satu nilai dengan nilai yang lain, pemantapan dan perioritas nilai yang dimilikinya. Yang termasuk dalam organisasi ialah konsep tentang nilai, organisasi sistem nilaidan lain-lainnya.

e. Karekteristik nilai atau internalisasi nilai yaitu keterpaduan semua sistem nilai yang teleh dimiliki seseorang, yang mempengaruhi pola kepribadian dan tingka lakunya.

3. Prestasi belajar psikomotorik

Ranah psikomotorik tampak dalam bentuk dkil (ketrampilan )dan kemampuan bertindak induvidu. Ranah psikomotorik terbagu menjadi lima kategori yaitu:

a. Peniruan yang terjadi ketika siswa, mengamati suatu gerakan dan mulai memberi respon yang serupa dengan yang diamati. Pada umumnya peniruan yang terjadi dalam bentuk global yang tidak sempurna.

b. Manipulasi, yang menekankan pada perkembangan kemampuan mengikuti pengharapan,penampilan gerakan-gerakan pilihan dan 
menetapkan suatu penampilan melalui latihan. Pada tingkat ini tidak sekedar meniru tingka laku tetapi menampilkan suatu menurut petunjukpetunjuk.

c. Ketetapan, mereka yang yang memerlukan kecermatan,dan kepastian yang memiliki dalam penampilan. Respon-respon telah terkoreksi dan kesalahan-kesalahan telah dibatasi pada tingkat minimum.

d. Arkulasi, yang menekankan pada koordinasi satu rangkain gerakan dengan urutan yang tepat dan adanya konsisten internal antar gerakangerakan berbeda.

e. Pengalaman, dimana tingka laku yang ditampilkan paling sedikit mengeluarkan energi fisik dan psikis. Selain itu gerakannya juga dilakukan secara rutin.

\section{MANFAAT KOMPETENSI GURU TERHADAP PRESTASI BELAJAR}

Sudah jelas bahwa guru sebagai agen transformasi pengetahuan bagi peserta didik, apabila guru konsisten menjalankan tanggung jawabnya sebagai guru yang professional, maka akan tercapai prestasi peserta didik. belajar:

Beberapa di bawah ini kemampuan minimal guru dalam mencapai prestasi

1. Mampu menguasai ilmu pengetahuan sesuai bidangnya. Sebagai contoh guru Pendidikan Agama Kristen, harus mampu menguasai Dogmatika, Teologi dan Biblika

2. Mampu menjembatani antara persoalan sehari-hari yang dihadapi peserta didik dengan mengadakan dorongan dan konseling.. Tugas guru adalah menjebatani antara pendidikan dan pembelajaran.

3. Menguasai bahan ajar

Bahan ajar yang disampaikan kepada peserta didik harus harus terlebih dahulu dikuasai dan dihayati oleh guru. Hendaknya guru memahami makna topik yang diajar sehingga ia mampu membagikan kepada peserta didik. Bahan yang dikuasai akan dikomonikasikan dengan baik pula kepada peserta didik.

4. Menguasai prinsip-prinsip pendidikan

Prinsip-prinsip pendidikansecara umun harus dikuasai oleh guru. Prinsipprinsip tersebut meliputi hubungn antara guru dan peserta didik, hakekat belajar mengajar secara umum, dan khusus.

5. Mampu mengelola program belajar mengajar.

Program belajar mengajar terutama mencakup langkah pembelajaran. Hal ini harus dikuasai dengan baik sehingga guru dapat mengelola kelas, terutama ketika berhadapan dengan situasi tertentu yang tidak diduga sebelumnya. Pengusaan belajar mengajar memampukan guru untuk bersikap fleksibel dalam memngatur program belajar mengajar situasi dan kondisi. Mengelola pembelajaran berarti memberi gambaran sikuensi materi pembelajaran yang akan dikaji dalam satu semester.

6. Dalam Sylabus telah dimuat rumusan Stansdart Kompetensi dan Kompetensi Dasar sebagai arah atau kompas tujuan pembelajaran, dalam setiap materi pokok pembelajaran.. Selain Sylabus gurun juga harus cakap dalam merencanakan pelaksanaan pembelajaran (RPP), dimana disusun dalam 1-3 kali sebagai persiapan mengajar guru yang lebih spesifik. Dalam 
RPP memuat kegiatan pelaksanaan pembelajaran baik kegiatan inti maupun kegiatan pelengkap seperti membuka dan menutup pembelajaran.

7. Mampu menggunakan beragam media dan sumber belajar dalam rangka proses belajar mengajar. Penggunaan media pembelajaran merupakan cara cerdas yang dapat menghasilkan kelas yangselalu baru dalam tiap kali pertemuan. Tetapi hendaknya diingat bahwa penggunaan media dan sumber belajar harus disesuaikan dengan situasi kelas dan topic pembahasan supaya seluruh proses pembelajaran saling berkait kompotensi pembelajaran tercapai.

8. Mampu mengola kelas.

Keberhasilan program belajar mengajar sangat ditentukan oleh kemampuan guru dalam mengelola kelas. Pengelola kelas meliputi: pemahaman karakteristik peserta didik, dan kemampuan membaca situasi, terutama ketika peserta didik kelihatan jenuh, lesu dan kurang memahami topic yang disampaiksan.

9. Mampu membangun interaksi positif antara guru dan peserta didik.

10. Mampu membimbing dan membina peserta didik dalam proses mencapai transformasi nilai-nilai kehidupan sebagai murid Yesus.

11. Mampu menggunakan berbagai hasil penelitian dalam peningkatan visi dan kemampuan dalam mengembangkan metodelogi dalam mengajar.

12. Mampu menguasai prinsip-prinsip evaluasi belajar.

Penguasaan terhadap evaluasi yang sesuai dengan kompotensi, indikator kompotensi, dan materi melaksanakan evaluasi belajar sesuai dengan rancangan, menganalisis hasil evaluasi untuk kepentingan mutu proses belajar mengajar.

13. Mampu membangun karakter dan integrasi yang baik.

14. Melaksanakan Evaluasi Hasil Belajar. Tujuan dilakukannya evaluasi menurut Muhibbin Syah adalah Pertama, untuk mengetahui tingkat kemajuan yang teleh dicapai oleh peserta didik dalam kurun waktu belajar proses tertentu. Kedua, Perlu mengetahui posisi atau kedudukan seorang peserta didik dalam kelompok kelasnya. Ketiaga, Untuk menyetahui tingkat usaha yang dilakukan peserta didik dalam belajar. Keempat, Untuk mengetahui sejauh mana peserta didik mendayagunakan kapasitas konitif (kemampuan kecerdasan yang dimiliki) untuk kemampuan belajar. Kelima, Untuk mengetahui daya guna dan hasil guna metode mengajar yang telah digunakan guru dalam proses belajar mengajar.

Setiap orang yang melakukan proses belajar akan memiliki tujuan. Tujuan pembelajaran diantaranaya untuk mencerdaskan peserta didik setelah adanya belajar. Proses pembelajaran merupakan suatu prosesyang kerkait erat dengan kondisi-kondisi tertentu. Oleh sebab itu pencapain hasil pembelajaran (hasil belajar) juga terkait dengan kondisi-kondisi tertentu baik yang ada dalam diri peserta didik maupun berasal dari luar peserta didik seperti yang telah diuraikan di atas.

\section{Faktor-Faktor yang Mempengaruhi Prestasi Belajar}

Dalam mencapai prestasi belajar yang baik seorang anak selalu dipengaruhi oleh berbagai macam faktor yang terjadi disekitar kehidupannya. Baik yang terjadi 
lingkungan sekolah maupun lingkungan keluarga, teman dan masyarakat. Menurut Merson U. Sanggalang,faktor yang mempengaruhi prestasi adalah :"kecerdasan, bakat, minat, dan perhatian, motif kesehatan, lingkungan keluarga dan pergaulan, lingkungan sekolah dan sarana pendukung belajar, faktor lingkungan rumah atau keluarga sangat mempungaruhi untuk peningkatan prestasi belajar peserta didik, orang tua yang menaruh perhatian yang baik pada anaknya dalam belajar di rumah akan anak merasa diperhatiakn orang tuanya sehingga menambahkan semangat belajar anak.

1. Faktor orang tua

Orang tua yang bijaksana yang memiliki keinginan agar anaknya prestasi tinggi dalam belajar harus melati anak-anaknya untuk melengapkan segala rintangan yang dihadapi dalam masa belajarnya. Orang tuanya yang kurang memperhatikan pendidikan anaknya juga harus memperhatikan kemampuan dan kecerdasan anaknya serta memberikan bimbingan yang sesuai dengan kepribadian anaknya.

2. Faktor pergaulan

Faktor pergaulan anak juga sangat mempengaruhi pretasi belajar peserta didik sebab anak yang bergaul dangan anak yang peserta didik belajarnya tinggi kemungkinan besar akan mempengaruhi temannya secara positif dalam prestasi belajar anak.

3. Faktor lingkungan sekolah

Di dalam lingkungan sekolah peserta didik juga hendaknya mendapatkan proses balajar yang baik, dari pihak guru harus bmengajar secara profesional serta menjujung tinggi tugas dan tanggungjawab sebagai guru kebijakan mencapai prestasi belajar baik, peserta didik sangatlah dipengaruhi lingkungan bergaulnya lingkungan anak selalu membaerikan pengaruh dalam perkembangan belajar anak sesuai dengan hubungan yang mempengaruhi perilakunya setiap hari.

Menurut Singgih D. Gunarsa mengatakan:"makain bertambah unsur,si anak makin memperoleh lebih luas untuk mengadakan hubungan-hubungan dengan teman-teman bermain yang biasanya sebaya atau seumur dengan dirinya, sekalipun dalam kenyataan perbedaan umur yang relatif besar tidak menjadi sebuah sebab tidak adanya kemungkinan melakukan hubungan-hubungan dengan nuasa berteman.

Oleh karena lingkungan sangat mempengaruhi perkembangan peserta didik dalam mencapai prestasi belajarnya maka orang tua sangat berperan dalam mengawasi anak. Pengaruh dari diri anak dalam memcapai prestasi belajar yang baik sngat mempengaruhi misalnya kepercayaaan diri anak itu sendiri. Thamarin Nasution mengatakan bahwa dalam belajar seseorang anak haruslah membiasakan diri anak untuk memiliki kepercayaan akan diri sendiri. Sebab dengan dasar inilah seorang anak akan dapat membina diri dan mempertinggikan prestasinya di sekolah.

\section{KESIMPULAN}

Prestasi belajar peserta didik tidak dapat dipisahkan dengan kompetensi guru secara akurat dan profesional. Guru adalah sebagai jabatan profesi, untuk itu dituntut cakap dalam menjalankan tugasnya. Guru trampil sejak dari merencanakan pembelajaran, mengorganisasi materi pembelajaran, merumuskan strandar kompetensi dan kompetensi dasar. Memilih alat dan metode pembelajaran, kegiatan belajar dan evaluasi pembelajaran. Dengan demikian pendidikan di Indonesia dapat segera meningkat, dapat bersaing dengan negara-negara lain di dunia. 
VOL. 1 NO. 2 EDISI JULI-DESEMBER 2018. ISSN. 262 1-2684

\section{DAFTAR KEPUSTAKAAN}

Undang-Undang Republik Indonesia No. 20 Tahun 2003 Tentang Sistem Pendidikan Naional, Bandung: Citra Umbara, 2003.

UU Nomor 14 tahun 2005, Tentang Guru dan Dosen, Bandung: Citra Umbara, 2005.

Adiningsih, UU. Kalitas dan Profesionalisme Guru, Pikiran Rakyat, online Oktober 2002. Http/www.pikiranrakyat.com

Amir Dien Indra Kusuma, Pengaruh Ilmu Pendidikan, Surabaya: Usaha Nasional, 1973.

E.Mulyasa, Standar Kompetensi dan Guru, Bandung: Remaja Rosda Karya, 2007.

Kamus Besar Bahasa Indonesia, Depdikbud, Balai Pustaka, 1988.

M. Nalim,Purwanto, Psikologi Guruan,Bandung:Remaja Karya,1989.

Moh.Uzer Usman, Menjadi Guru Profesional, Bandung: Remaja Rosda Karya Offset,1998.

Nana Sujana, Cara Belajar Siswa Aktif,cet. II, Bandung:Sinar Baru1986.

Slameto, Belajar dan Faktor-faktor yang Mempengaruhinya, Jakarta:Rineka Cipta, 2003.

Sudarwan Danin, Agenda Pembaruan Guruan, Yogyakarta:Pustaka Pelajar, 1991.

Syaiful Bahri Djamalah, Prestasi Belajar dan Kompetensi Guru, Surabaya:Usaha Nasional, 1994. 